\title{
An Assessment of Internet Uses, Practices, and Barriers for Professional Development by Agricultural Science Teachers in Lagos State
}

\author{
Olatomide Waheed Olowa \\ Department of Agricultural Education, Federal College of Education (Technical), Akoka, P.O. Box 269, Yaba, Lagos, Nigeria \\ Correspondence should be addressed to Olatomide Waheed Olowa, olowa1@yahoo.com
}

Received 5 March 2012; Revised 19 May 2012; Accepted 20 May 2012

Academic Editor: Gwo-Jen Hwang

Copyright ( 2012 Olatomide Waheed Olowa. This is an open access article distributed under the Creative Commons Attribution License, which permits unrestricted use, distribution, and reproduction in any medium, provided the original work is properly cited.

The paper reports a study carried out on the utilisation of the Internet by agricultural science teachers in Lagos state focusing on uses, practices, and barriers. A questionnaire was developed based on literature and was administered to 300 agricultural science teachers in Lagos schools. 275 questionnaires properly completed were analyzed. Data reveal that 130 teachers are using the Internet for teaching agricultural science in classrooms as well as for various activities that enhance their professional development. Nevertheless, it was found that agricultural science teachers in Lagos State have not fully utilised the Internet because of barriers related to time factor, accessibility, and facilities. It is suggested that for the proliferation of Internet practices, there needs to be an increase in funding for technology, an introduction of computer/technology education, a provision of pedagogical training for teachers, and a provision of administrational support.

\section{Introduction}

The use of Information and Communication Technology (ICT) is becoming progressively more widespread throughout various sectors including education, business, as well as agriculture. One of the most popular ICT applications is eLearning. With e-Learning, we can use available technologies to enhance learning and expand access to education and training in the agricultural sector. According to the Technical Centre for Agricultural and Rural Cooperation (CTA) [1], ICT are technologies which facilitate communication and thus the processing and transmission of information electronically. Akpabio et al. [2], using the definition of the United States Agency for International Development, clarify that ICT includes technologies and methods for storing, managing and processing as well as communicating information. Adebayo and Adesope [3] describe ICT as scientific, technological, and engineering disciplines, and the management technologies used in the handling of information, processing, and applications related to computers.
ICTs are a relatively recent instrument in the fight to eliminate hunger and poverty. It is the power behind globalization and the underpinning issues. Internet as a component is a tool that has immense potentials in encouraging and facilitating teaching and learning of agricultural science. As a new way of acquiring and facilitating the processing of information, the Internet can encourage learners not only to view themselves as being in charge of their own learning, but also to perceive teachers as facilitators in the learning process. Hence, in terms of education it is becoming increasingly feasible to think in everyday terms about the practical applications of learning, which rely upon Internet and mobile communications [4]. The reason for such a positive outlook of classroom dynamics is because with the Internet, there are a myriad of educational opportunities and resources for the learners to get exposed to.

A general lesson from initiatives that employ ICT for development is that successes are possible, but programs must be designed and implemented with care. Early enthusiasm and claims that ICT would prove to be a panacea 
for development problems led to a number of false starts that have given ICT rather a bad reputation in mainstream development circles. After years of debate in the field of agricultural engineering about rusting tractors or failed infrastructural projects, and years of experience built up in participatory communications, there are the feelings that the same mistakes and shortcomings are being replicated in the rush to make the benefits of new ICTs available to all. There are examples of government or nongovernmental organisations sponsored telecentres lying empty, equipment abandoned, stolen, or being used only by the privileged few members of the society. What has been learnt from such "rusting tractor" scenarios is that success is not derived from inserting advanced communication technology into a poverty-stricken social context, with attendant low levels of literacy and empowerment, and expecting positive transformation. The difference ICTs can make, particularly in the area of agricultural development and food security, was among the issues addressed during the World Summit on the Information Society (WSIS) Plan of Action. The plan argues that comprehensive countrywide information systems fulfil clear important need. Information and Communication Technologies (ICTs) are the basis for such systems. The plan calls for measures to ensure the systematic dissemination of information using ICTs to teach agriculture in such areas such as animal husbandry, fisheries, forestry, and food in order to provide ready access to comprehensive, upto-date and detailed knowledge and information, particularly in rural areas. In 2003, the Building Communication Opportunities Programme (a partnership of development organisations engaged in using ICTs for development) reviewed experiences of its members in supporting programmes designed to use ICTs for poverty reduction in subSaharan Africa. The study concluded that in many instances the programmes were successful in generating increased quantities of food crops, as well as additional amounts of cash in poor households. The programme contributed to poverty reduction, the availability of food, and improvement of literacy and healthcare of the beneficiaries.

Though it is quite obvious that we have already entered a new information age, which links technology and the teaching of agricultural science for increased food production, the prospects of the Internet for educational use have not been fully explored in some countries and the average schools in these countries only use Internet to a limited extent. This limited use is mainly because of the lack of facilities in schools, high cost of accessing to Internet, and teachers' lack of knowledge and skills in using Internet for educational purposes. This paper investigates the utilisation of the Internet by agricultural science teachers in Lagos state with a focus on uses, practices, and barriers to internet. It also $\mathrm{X}$-rays the extent of Internet contribution to teachers' overall professional development.

\section{Literature Review}

The integration of computer-mediated communication (CMC) and Internet technologies have the potential to support learning. The experiential learning can be in the form of providing effective feedback to learners, enabling pair and group work, enhancing student achievement, providing access to authentic materials, facilitating greater interaction, and individualising instruction. In addition, $\mathrm{CMC}$ and related technologies allow independence from a single source of information and motivate learners [5]. In addition, integration of such technology in the classroom can have a positive impact on development of skills and learners attitudes in school [6].

Since the mid 1990s, educators have begun using the Internet resources for a variety of instructional purposes and favouring electronic classroom environments in which students are able to and are expected to (1) take charge of their own learning, (2) learn to think critically and analytically, (3) work collaboratively, and (4) create products to demonstrate what they have learned. In doing so, according to Coley [7], educators are confronted by a number of methodological and practical issues. Such issues include: (a) they need to remember that technology is only one component of an instructional activity, (b) assessments of the impact of technology are really assessments of instruction enabled by technology, and (c) the outcomes are highly dependent on the quality of implementation of the instructional design.

The emphasis on technology, CMC, and the Internet in classrooms should address teachers' approach to teaching as well as the ways of learning should move from a teachercentred to a more student-centred approach. Nigerian teachers are now experiencing similar change of roles as they begin to integrate Internet into their teaching and learning activities. Levy [8] claims that the use of Internet resources in teaching can free teachers from isolated materials production role, which have always been time and effort consuming. Teachers can make use of materials produced by recognised educational organisations experienced teachers for teaching students. In this way, the teachers' role becomes expanded to encompass facilitating of knowledge since ICT/internet facilities could provide most of learning materials, irrespective of teachers' limited knowledge in computer programming or software.

Alomari [9] and Maor [10] argue that teachers should take on the roles of researchers and facilitators who engage students to become involved in active, collaborative, and constructive learning experiences. However, without teachers who are expected to organise the resources and contextualise the learning experiences contained in the curricula, the power of the Internet will dissipate and the teaching potential will be lost. Therefore, teachers need to engage in roles that include not only using technology appropriately, but also finding ways to build-in purposeful connection and relationship to the larger world and immediate community outside the school environment. Hence, teachers' practices of the Internet have to mirror their new roles so that learning experiences can be enhanced and enriched through engaging learners in authentic and meaningful activities that the Internet can facilitate and support. Earlier studies have explored such possibilities with quite exciting outcomes. LeLoup [11], for instance, noted that e-mail provides teachers the access to news and discussion groups, which in turn allowed teachers 
TABLE 1: Internet usage and population growth in Nigeria.

\begin{tabular}{ccccc}
\hline Year & Users & Population & $\%$ Pen. & Usage source \\
\hline 2000 & 200,000 & $142,895,600$ & $0.1 \%$ & ITU \\
2006 & $5,000,000$ & $159,404,137$ & $3.1 \%$ & ITU \\
2009 & $23,982,200$ & $149,229,090$ & $16.1 \%$ & ITU \\
\hline
\end{tabular}

Source: Internet World Stats [15].

to design activities and projects that enhance curriculum. These discussions allowed the teachers to gain confidence, learn, and rely on and support each other. Also, through networking on internet, agricultural science teachers contribute to mutual encouragement and recognition amongst themselves. This is done by giving positive feedback on ideas, materials, and classroom practices for the benefit of learners. Also, the Internet offers agricultural science teachers the opportunity for collaborative professional development through various online activities such as online sharing, online collaboration, and online researching [12-14], all of which that contribute to better classroom practices in terms of teaching and learning of agricultural science.

\section{Internet in Nigeria}

Federal Republic of Nigeria is the most populous country in West Africa in particular and the African continent. Nigeria shares land borders with the Republic of Benin in the west, Chad and Cameroon in the east, Niger in the north, and the Gulf of Guinea in the south. Since 1991, its capital has been the centrally located Abuja. There are 23,982,200 Internet users as of December 2009, representing $16.1 \%$ of the population, according to International Telecommunication Union (ITU) (2010) (Table 1).

The cost of going online in Nigeria, as compared to other African countries, is relatively higher. For instance, the dialup access costs between 5,000 and 10,000 per month in a society where the minimum wage is 18,000 per month. The Internet for people of Nigeria is a world in itself that has nothing to do with borders. As such, the Internet is highly valued by the people of Nigeria mainly because of its ubiquitousness, far reaching, and connections to people and communities. This is further enhanced by the fact that Nigerians are increasingly becoming more computer literate.

In recent times, Nigerians have recorded a higher usage of the Internet. For example, in year 2000, 200,000 that is $0.1 \%$ of the Nigerian population were Internet users. As at 2006, the number of Nigerians who had accessed the Internet increased significantly to $5,000,000$, that is, $3.1 \%$ of the Nigerian population and by $2009,23,982,200$ Nigerians have accessed the internet [15]. This rapid increase is mainly because of the increase in services and facilities that the telecommunication and Internet companies in Nigeria are providing. This tremendous increase of Internet access indicates that the Internet in Nigeria has challenged all odds and is comparable to the ICT practices of other countries in terms of Internet connectivity and excellence in the desire for implementation of ICT in all aspects of life.
The Internet has brought significant changes to Nigeria's education landscape. Nigerian teachers are quite capable of using the Internet to assist them in their daily teaching activities such as preparing teaching materials, presentations, and homework. This is as a result of the strong thrust initiated by the various States Ministry of Education that incorporate information technology in school curricular. This incorporation brings new dilemmas and challenges within a larger strand of change that teachers are constantly expected to learn and cope up with. The integration of computer and ICT into the school curricular is of high priority as most schools in Nigeria are equipped with computer laboratories to cater for computer literacy programmes of the students. By connecting these labs to Internet, it was expected to enhance the quality of education in all fields particularly for the teaching and learning of agricultural science. In addition, it is the aspiration of the various States Ministry of Education to utilise and integrate Information Communication Technology (ICT) for the purpose of teachers' professional development.

The use of the Internet in agricultural science instruction in Nigeria is still at its infancy stage. Understandably, no empirical attempt has been made to investigate agricultural science teachers' Internet uses, practices, and barriers in Nigeria. Hence, this study attempts to shed some light on Agricultural Science teachers' uses, practices, and barriers of using Internet as an instructional tool in schools in Lagos State. In addition, this study will also examine the contribution of Internet to the teachers overall professional development. Although there is an adequate knowledge base and empirical research about the impact of technology particularly the Internet on student outcomes in other contexts. There is a pressing need for such a study in Lagos, the centre of excellence in Nigeria. The findings of this study will help researchers and administrators to comprehend the needs of Agricultural Science teachers in terms of Internet uses. In addition, such research will pave the way for more extensive and in-depth empirical research of this nature in a country where the Internet is seriously transforming the sociopolitical lives of its people.

The research questions for this study are.

(1) To what extents does agricultural science teachers' use the Internet?

(2) What are agricultural science teachers' practices of using the Internet for agricultural science teaching?

(3) What are the barriers that hinder agricultural science teachers' use and practices of the Internet in terms of agricultural science teaching?

(4) To what extent does the Internet contribute to the overall professional development of the agricultural science teachers in Lagos state?

\section{Methods}

The state has 906 primary schools with 859456 pupils. The state also has 360 secondary schools with 633247 students, 5 Technical Colleges with 3223 students, two Colleges 
of Education, about 50,000 full-time teachers of various disciplines and subjects. There are about 1200 full-time Agricultural Science teachers [16]. A research assistant, who is familiar with the government schools and knows the school Principals and Agricultural Science teachers in the city of Lagos, was contacted via telephone, and was briefed about the research and the questionnaire. 300 full-time Agricultural Science teachers, who were teaching in government primary and secondary schools in Lagos state, and more importantly, who were willing to participate in the study were contacted. The information of these Agricultural Science teachers was obtained through the "snowballing" technique, that is getting names and contact information of full-time Agricultural Science teachers through the Research Assistant's contacts and personal networking.

A survey was the most effective research method in answering the research questions of this study, as well as reaching teachers to obtain data. Questionnaires were given to the teachers personally. The 300 teachers answered the questionnaires. The research assistant then compiled the questionnaires and sent them to the authors by post. A total of 275 completed questionnaires were returned with a response rate of $91.7 \%$. The participants comprised 142 males and 133 females.

\section{Instruments and Data Analysis}

The instrument used was a questionnaire that consisted of four major dimensions: (a) demographic information, (b) Internet uses, (c) practices of Internet, and (d) barriers of Internet use as adapted from Kabilan [17] and Kabilan and Mohamed Amin [18]. The specific constructs or dimensions that were adapted were identified based on their relevance to the research questions for this study. Each item in the dimensions was then closely examined for relevance and suitability in the context of the Agricultural Science teachers and the teaching of Agricultural Science in Nigeria. As a result, some of the items were rephrased or reworded to ensure that Agricultural Science teachers were able to understand them. Three experts in the field of ICT reviewed and revised the questionnaire for its content validity. The questionnaire was piloted using thirty (30) teachers from five (5) schools in Shomolu Local Government Areas. The reliability index obtained from the pilot study is $r=0.81$, indicating that the questionnaire had a high level of internal consistency.

Based on the pilot study, the number of items in the practices of the Internet dimension was increased to at least ten items per subdimensions. The Internet uses dimension encompassed (1) Internet access and (2) amount of time spent using the Internet (hours per week). The Internet practices dimension had three subdimensions: (1) degree of importance of Internet activities using e-mails, chat rooms, messenger tools, and online forums (12 items), (2) degree of importance of Internet activities using World Wide Web (www) or web pages (10 items), and (3) degree of importance of the overall use of Internet for teachers' professional development (10 items). All the three subdimensions had
TABLE 2: Agricultural science teachers' reasons for not using the internet.

\begin{tabular}{lcc}
\hline Reasons for not using the internet & Yes $f(\%)$ & No $f(\%)$ \\
\hline (1) Do not know how to use computer & $102(71)$ & $42(29)$ \\
(2) No time to learn about the Internet & $81(56)$ & $63(44)$ \\
(3) No time to use & $64(44)$ & $80(56)$ \\
(4) No interest at all & $42(29)$ & $102(61)$ \\
\hline
\end{tabular}

a 5-point Likert response that ranges from "strongly agree" to "strongly disagree." To determine the teachers' uses and practices of the Internet, the gathered data were analysed using frequency, mean, standard deviation and percentages. The barriers of Internet use dimension have seven items that enquired the problems or difficulties that teachers faced in use and practices of internet.

\section{Results and Discussions}

Of the 275 returned questionnaires, only 130 (47.2\%) teachers indicated that they have access and use Internet for teaching and learning activities in classrooms and for professional development purposes. The remaining teachers ( $n=144)$ reported that they have not used the Internet at all for the purpose of teaching and learning in the classroom.

Agricultural Science teachers' reasons for not using the Internet are summarised in Table 2.

Most of the teachers do not use the Internet service mainly because they do not know how to use computer and they have no time to learn about the Internet. Only a proportion (29\%) of the teachers indicated that they have no interest at all in terms of using the Internet for teaching agricultural Science. Studies have shown that there are teachers who do not prefer online activities, and sometimes it is very difficult to encourage teachers' engagement in online activities [17]. This is because teachers have little or no knowledge and experience of technology or telecommunications in general [19]. This observation is in line with the findings of the results of this study. For the following sections, the data analysed and discussed concerns Agricultural Science teachers who have access to the Internet and have used Internet for the teaching of Agricultural Science.

\section{Agricultural Science Teachers' Use of Internet}

Table 3 shows the number of hours Agricultural Science teachers accessed and used Internet in a week (in hours). Majority of the teachers spent about 1-5 hours per week and $12.3 \%$ spent more than 20 hours per week.

Tables 2 and 3 show teachers' responses to accessibility to internet facilities and lack of time as key factors that hinder teachers' effective utilisation of the Internet in Lagos State. The same issues and problems have been identified earlier by Demirbilek [4] in the Turkish context, Kabilan and Mohamed Amin [12], Kabilan [17], Kabilan and Mohamed Amin [18] in the Malaysian context, and Kabilan and Rajab [20] in Palestine context. In the open-ended question of the 
TABLE 3: Overall usage of Internet in a week (hours) $(N=130)$.

\begin{tabular}{lc}
\hline Number of hours & $f(\%)$ \\
\hline $1-5$ & $56(43.1)$ \\
$6-10$ & $31(23.8)$ \\
$11-15$ & $18(13.8)$ \\
$16-20$ & $9(6.9)$ \\
More than 20 hours & $16(12.3)$ \\
\hline
\end{tabular}

problems faced by teachers in use of the Internet, despite that the 130 Agricultural Science teachers have access to the Internet, they still lamented that they have (i) difficulties accessing the Internet, (ii) lack the time, (iii) low level of connectivity, and (iv) cannot afford high cost of computers and Internet facilities. These issues, to some extent, have hindered the teachers' use and practices of Internet. Although the use of Internet helps overcome the problem of lack of time factor for some conventional form of professional development, it seems that the agricultural science teachers still do not have the time to use or learn more about the Internet. This is not surprising because teachers spend most of their time teaching, writing reports, cocurricular activities, disciplining students, meetings, checking and marking students' work, invigilation of examinations, and the list goes on.

Table 4 is the results of Agricultural Science teachers' responses to the degree of importance of the teachers' practices of Internet using; emails, chat rooms, messenger tools, and online forums. Agricultural science teachers in this study observed that the use and practices of Internet developed their communication skills, increased their communication levels with other teachers, and helped them to seek information relating to the teaching agricultural science. Other practices, as indicated in Table 4 , are equally important to agricultural science teachers, on the basis of the mean scores for each item. The teachers are most interested in making their teaching the best practice that would enable meaningful and effectual learning experiences for the learners. Thus, the teacher achieved by (1) increasing communication with teachers, (2) collaborating with other teacher, (3) giving professional support to other teachers, and (4) sharing and exchanging information. The most encouraging fact is that the teachers in this study indicated a strong willingness to use their own time to access the Internet for information that could help effective teaching of Agricultural Science despite the problem of lack of time that constitute a huge stumbling block. Kabilan and Mohamed Amin [13] argued that teaching practices can be improved through constant use of Internet applications, in which teachers are engaged in seeking information, collaborating, researching, sharing, and exchanging of ideas and knowledge.

Item with the lowest mean scores received professional support from teachers.

Agricultural Science teachers' practices of WWW were mainly to (i) search Agricultural Science-related information, (ii) be involved in a world of information, and (iii) find materials and read articles from online journals (Table 5). Equally important were teachers' activities of
TABLE 4: Teachers practices of the Internet (mean scores and standard deviation).

\begin{tabular}{lcc}
\hline Teachers practices & $\begin{array}{c}\text { Mean } \\
\text { scores }\end{array}$ & Std. dev. \\
\hline To develop communication skills & 4.41 & 0.643 \\
To increase communication between teachers & 4.23 & 0.677 \\
To combine new opinions with own & 4.17 & 0.649 \\
To enjoy when collaborating online with others & 4.15 & 0.821 \\
To give professional support to teachers & 4.12 & 0.722 \\
To develop a solid foundation for learning & 4.08 & 0.666 \\
To develop thinking skills & 4.02 & 0.698 \\
To share feedback by posting messages to & 3.99 & 0.773 \\
others & & \\
To receive professional support from teachers & 3.94 & 0.691 \\
\hline
\end{tabular}

TABle 5: Agricultural science teachers' practices of WWW.

\begin{tabular}{lcc}
\hline Teachers' practices & $\begin{array}{c}\text { Mean } \\
\text { scores }\end{array}$ & $\begin{array}{c}\text { Std. } \\
\text { deviation }\end{array}$ \\
\hline To search agricultural Sc.-related info & 4.31 & 0.692 \\
To be involved in a world of information & 4.25 & 0.778 \\
To find materials & 4.23 & 0.803 \\
To read academic articles from online journals & 4.21 & 0.804 \\
To present creative works & 4.11 & 0.838 \\
To experience creative works & 4.10 & 0.806 \\
To find exercises & 3.89 & 0.891 \\
To find questions for exams/tests & 3.87 & 0.968 \\
To find lesson plans & 3.80 & 1.030 \\
\hline
\end{tabular}

finding exercises, test papers, and questions and lesson plans. Table 5 indicates that teachers were willing to try to improve their teaching by engaging in activities such as search for Agricultural Science-related information, which include: reading academic articles, materials, exercises, questions, and lesson plans. It appears that teachers are interested in using Internet applications for the teaching and learning of agricultural science in Lagos state.

Agricultural Science teachers in this study indicated several barriers that seriously hindered their Internet use and practices. These barriers include (1) lack of facilities (3.96), (2) high cost of Internet access (3.96), (3) lack of time (3.72), and (4) slow speed connection (3.72) (see Table 6). Only a small number of the teachers admitted that they lack knowledge in use of Internet.

\section{Overall Contribution of the Internet to Teachers' Professional Development}

Agricultural Science teachers in this study observed Internet as an important tool that can enhance their professional development. Teachers use the Internet to share ideas/views with other teachers, enhance professionally development, and improve teaching skills. The use of the internet creates 
TABLE 6: Mean scores and standard deviation of barriers faced by agricultural science teachers in use of internet.

\begin{tabular}{lcc}
\hline Items & Mean & Std. deviation \\
\hline Lack of facilities & 3.96 & 0.615 \\
High cost of internet access & 3.96 & 0.772 \\
Lack of time & 3.72 & 0.673 \\
Connection-speed too slow & 3.72 & 0.770 \\
Need to pay to get most academic materials & 2.81 & 0.916 \\
Too many hits for a particular topic & 2.32 & 0.788 \\
Lack of knowledge in use of internet & 2.18 & 1.098 \\
\hline
\end{tabular}

TABLE 7: The importance of internet's contribution to the overall professional development of the agricultural science teachers (mean scores and standard deviation).

\begin{tabular}{lcc}
\hline Items & Mean & $\begin{array}{c}\text { Std. } \\
\text { deviation }\end{array}$ \\
\hline To share ideas/views with other teachers & 3.72 & 0.981 \\
To grow professionally & 3.70 & 1.001 \\
To improve teaching skills & 3.68 & 0.973 \\
To be aware of the latest development in & 3.62 & 0.959 \\
agriculture & & \\
To expand experiences for career/promotion & 3.53 & 0.933 \\
purposes & 3.52 & 0.958 \\
To learn new skills related to agric. practices & 3.52 & 0.900 \\
To prepare self for innovation & 3.49 & 0.966 \\
To facilitate thinking abilities & 3.48 & 0.925 \\
To gain motivation & 3.34 & 0.936 \\
To remain interested in teaching & & \\
\hline
\end{tabular}

great awareness of the latest developments in the field of agriculture (Table 7).

When asked if the Internet has had positive impact on the teachers' practices of teaching and learning, 127 teachers (97.7\%) reported that the Internet was useful and likely to lead to significant changes in the way the teachers teach in the near future. Agricultural Science teachers' positive view of the Internet's contribution to their professional development indicates that Internet as a tool for global connectivity for retrieving information and keeping in touch with the latest news, ideas, and approaches to the teaching and learning of Agricultural Science. Hence, Internet has a huge potential of engaging teachers' collaboration with other teachers outside Nigeria, especially for the construction of knowledge, and ideas. This study provides a clear indication that teachers are not lagging behind in terms of information, knowledge, and professional development through the use and practice of Internet that kept them abreast of the current educational development, especially in the field of teaching agricultural science. The current trends of research and practice in enhancing teachers' professional development using the Internet tools (or online professional development) is geared towards a more self-managed and self-directed process of professional development" [14]. With such use of the Internet, teachers actually have the opportunities to learn and gain valuable competencies such as computing and communicating skills and creative and critical thinking. From the findings of this study, it is evident that the Agricultural Science teachers are quite aware of the potentials of the uses and practices of Internet to help them gain more competencies in the teaching and learning of Agricultural Science.

This self-managed and self-directed experience using Internet gives a real sense of ownership and relevance to online professional development activities through intellectual discourses, participating in collaborations, and sharing and exchanging experiences, views, ideas, and opinions. With abilities that is transcending time (synchronous and asynchronous) and geographical boundaries, Internet and its tools will soon enhance and boost teachers' professional development meaningfully on the basis of needs, interests, and expectations in Nigeria. In a rapidly globalizing world, Internet offers a platform and an opportunity for teachers to connect with other teachers from other regions without travelling. Internet services widens teachers' access to the abundance and myriad of resources, knowledge, ideas, and teaching materials that can be identified and utilised for teaching purposes. All these are contributions that the use and practice of internet will offer overall professional development of Agricultural Science teachers in Nigeria and specifically those in Lagos State.

\section{Conclusion}

This study examines Agricultural Science teachers' Internet uses, practices, and barriers in Lagos state. It also identifies that teachers hold high opinions and values for the use and practice of the Internet to their teaching assignment, as well as to overall professional development. They are also optimistic that they will widely use Internet which is likely to lead to significant changes in the way they teach in the near future. Nevertheless, the low utilisation and access to the Internet (only $47.2 \%$ of the agricultural science teachers in this study had access to the Internet or have used the Internet for teaching and learning of agricultural science) suggests that a lot more needs to be done to maximally harnessed the benefit and gain of Internet and its applications. The need to confront the barriers to the use and practice of internet is crucial. Thus, these barriers to teachers' practices of the Internet should be addressed by the educational authorities at the state level, as well by the school administrators.

The teachers who have access to Internet in this study were more positive in terms of usage and demonstrable usefulness and meaningful practices in the teaching and learning of agricultural science and teachers overall professional development. Thus, in many ways, presenting itself as a key component of education and an important source of information for the agricultural science teachers in Lagos state. Therefore, the relevant educational authorities should take the initiative to encourage the use of the Internet for teaching agricultural science in Lagos state. The Youth Empowerment Scheme (YES) through agriculture could go a long way to achieve government objectives if ICT/internet 
facilities are adequately inculcated. This can be achieved by being more active and supportive in terms of

(i) increasing funding for technology (especially computers and Internet facilities and access);

(ii) introducing computer/technology education into existing curricular as well as teacher education and professional development programmes;

(iii) providing pedagogical training to enhance teachers' ability to acquire, appraise, and use information from Internet to create efficient, creative and critical methods of teaching and learning processes and;

(iv) providing administrational support in the form of providing networks, technical support, resources and facilities, and network time allocation to teachers.

All the above will greatly help agricultural science teachers in enhancing and enriching their use and practices of the Internet for teaching and learning agricultural science as well as their overall professional development.

\section{References}

[1] Technical Centre for Agricultural and Rural Cooperation (CTA), Annual Report 2003, Wageningen, The Netherland, 2003.

[2] I. A. Akpabio, D. P. Okon, and E. B. Inyang, "Constraints affecting ICT utilization by agricultural extension officers in the Niger Delta, Nigeria," The Journal of Agricultural Education and Extension, vol. 13, no. 4, pp. 263-272, 2007.

[3] E. L. Adebayo and O. M Adesope, "Awareness, access and usage of information and communication technologies between female researchers and extensions," International Journal of Education and Development Using Information and Communication Technology, vol. 3, no. 1, pp. 85-93, 2007.

[4] M. Demirbilek, "Exploring the status of ICT use in adult education: Perspectives from eight European countries'reflections, insights, and challenges," International Journal of Education and Development Using Information and Communication Technology, vol. 5, no. 3, pp. 1-21, 2009.

[5] K. Lee, "English teachers' barriers to the use of computerassisted language learning," The Internet TESL Journal, vol. 4, no. 12, 2000, http://iteslj.org/Articles/Lee-CALLbarriers.html.

[6] N. Mathew and M. Dehery-Poirier, "Using the World Wide Web to enhance classroom instruction," First Monday, vol. 5, no. 3, 2000, http://www.firstmonday.dk/issues/issue5_3/index .html.

[7] R. J. Coley, "A new Study shows theeffectiveness and limitations of school technology [Electronic Version]," Electronic School, 1997, http://www.electronic-school.com/0997f3.html.

[8] M. Levy, "Teacher education and CALL: the "Expert User's View" and the "Holistic View"," ON-CALL Journal, vol. 7, no. 2, pp. 19-23, 1993.

[9] A. Alomari, "Investigating online learning environments in a web-based math course in Jordan," International Journal of Education and Development Using Information and Communication Technology, vol. 5, 2009, http://ijedict.dec.uwi.edu/ viewarticle.php?id=700\&layout=html.

[10] D. Maor, "The teacher's role in developing interaction and reflection in an online learning community," Educational Media International, vol. 40, no. 1-2, pp. 127-138, 2003.
[11] J. LeLoup, "But I only have e-mail—what can I do?" Learning Languages, vol. 2, no. 2, pp. 10-15, 1997.

[12] M. K. Kabilan and E. Mohamed Amin, "A nationwide survey of Malaysian English language teachers' online networking practices," Internet Journal of e-Language Learning and Teaching, vol. 1, no. 1, pp. 52-64, 2004.

[13] M. K. Kabilan and E. Mohamed Amin, "English language teachers' professional uses of e-mail," Teacher Development, vol. 10, no. 1, pp. 87-103, 2006.

[14] M. K. Kabilan, "Online professional development: an analysis of teacher competency," Journal of Computing in Teacher Education, vol. 21, no. 2, pp. 51-57, 2005.

[15] Internet World Stats, Nigeria Internet Usage and Popula- tion Statistics, 2010, http://www.internetworldstats.com/stats5 .htm.

[16] Nigeria Muse, Students' Enrolment in Public School Lagos, 2010.

[17] M. K. Kabilan, "Online professional development of teachers: an examination of structure and trends in Malaysia," International Journal of Instructional Media, vol. 30, no. 4, pp. 367382, 2003.

[18] M. K. Kabilan and E. Mohamed Amin, "English language teachers' experiences of online professional development: an initial study," Malaysian Journal of Distance Education, vol. 4, no. 1, pp. 47-60, 2002.

[19] J. Levin and C. Thurston, "Research summary: educational electronic networks," Educational Leadership, vol. 54, no. 3, pp. 46-50, 1996.

[20] M. K Kabilan and B. M. Rajab, "The utilisation of the Internet by Palestinian English Language teachers focusing on uses, practices and barriers and overall contribution to professional development," International Journal of Education and Development Using ICT, vol. 6, no. 3, pp. 56-72, 2010. 


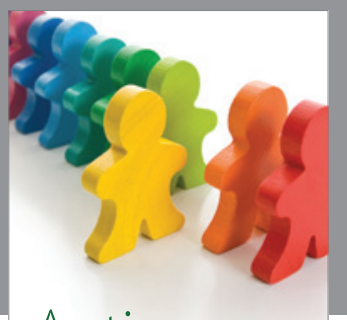

Autism

Research and Treatment
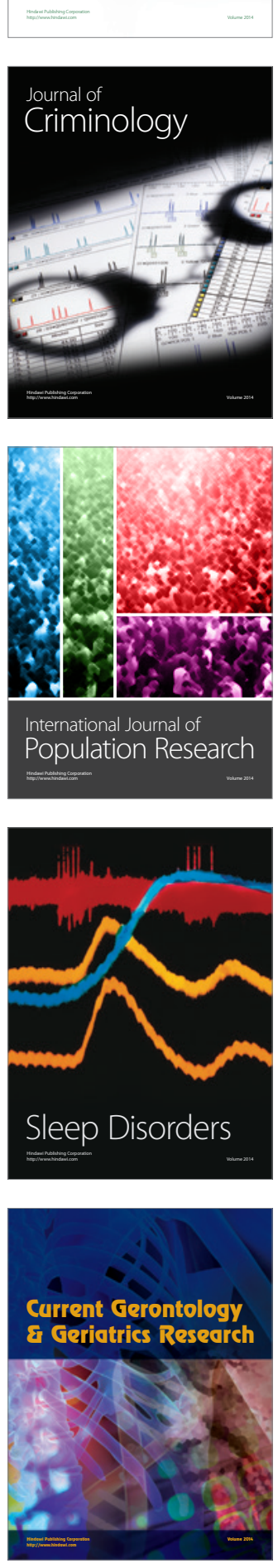
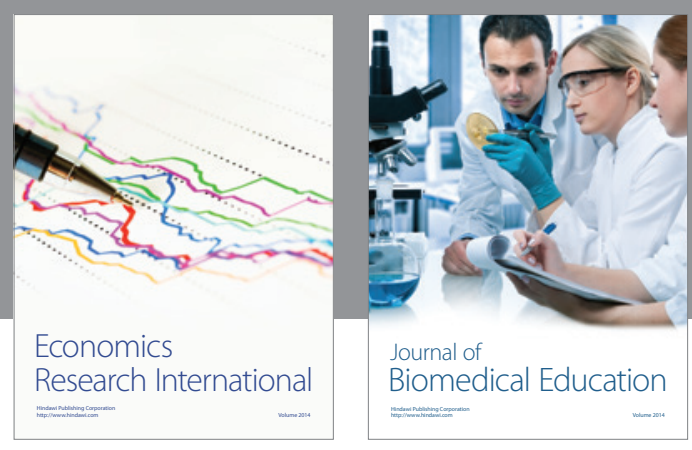

Journal of

Biomedical Education

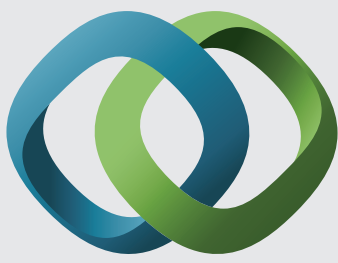

\section{Hindawi}

Submit your manuscripts at

http://www.hindawi.com
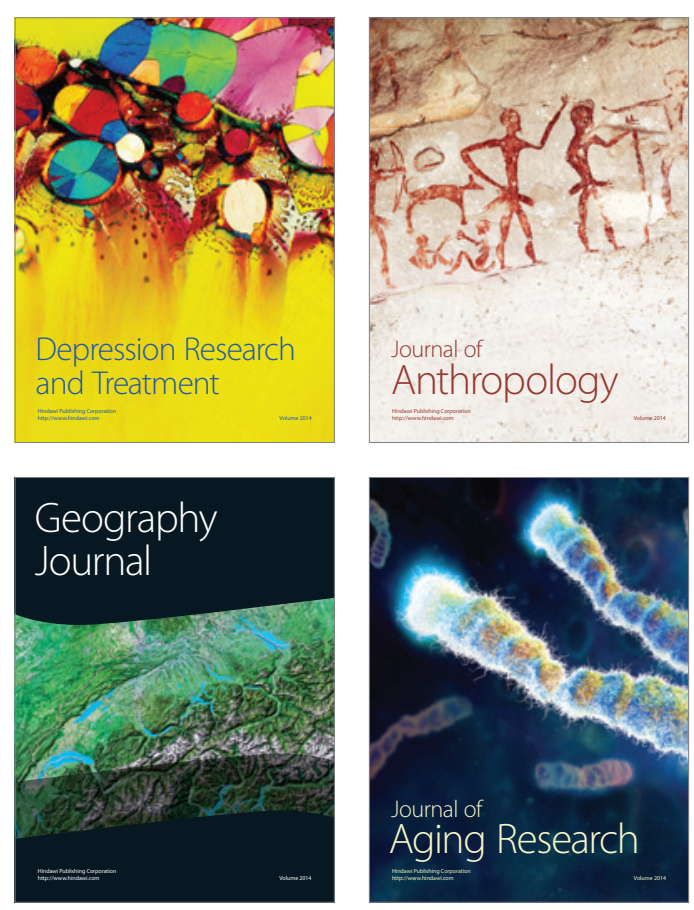

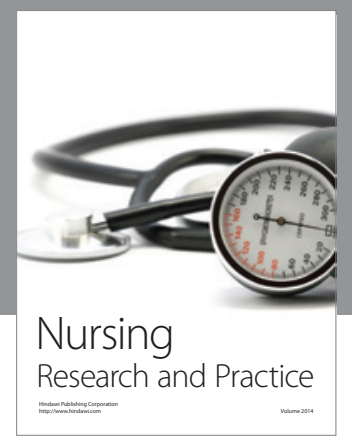

Nursing

Research and Practice

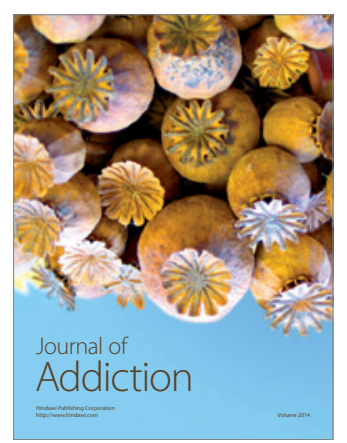

Child Development

Research

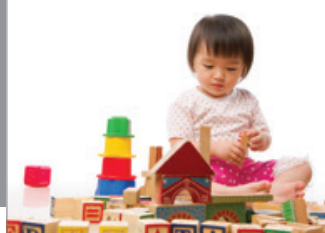

迥
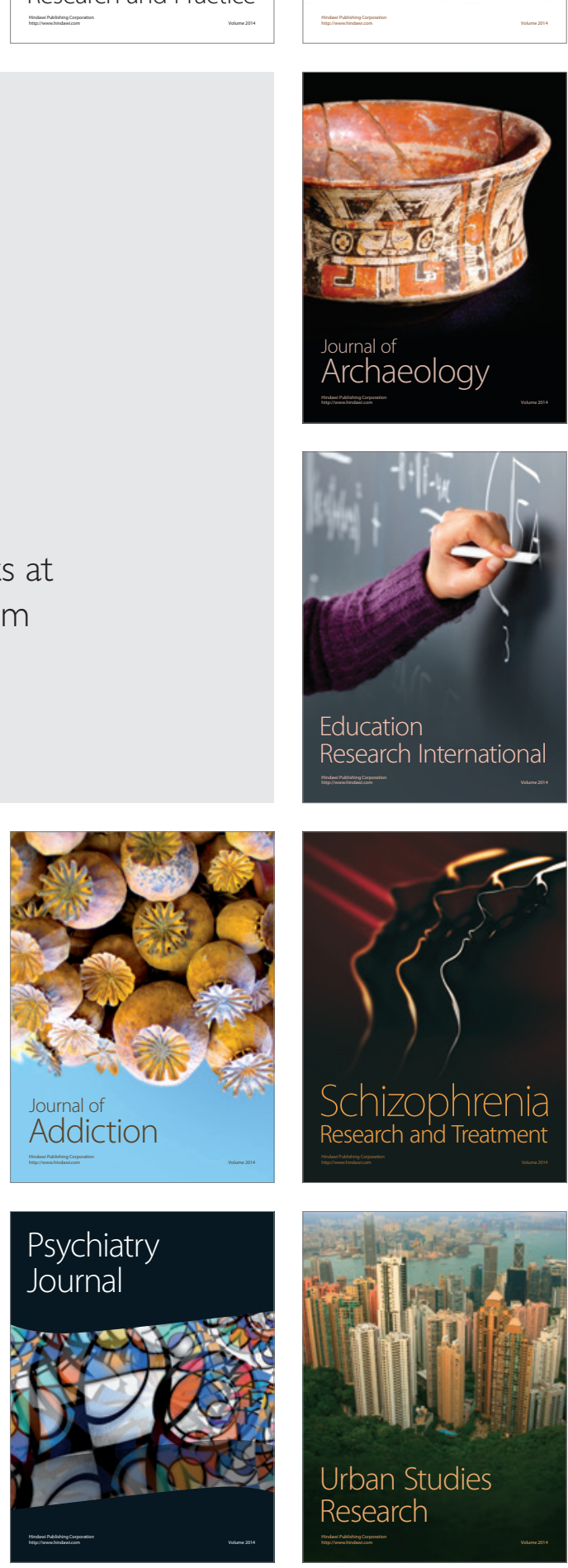